\title{
Don Ricardo y su hijo Clemente, dos desterrados políticos en tierras del Mapocho
}

Por Juan Carlos Adriazola Silva 
Licenciado en Ciencias de la Información por la Universidad Particular de Piura. Magíster en Ciencias de la Educación, especialidad en Docencia e Investigación por la Universidad Nacional Pedro Ruíz Gallo de Lambayeque. 


\section{Introducción}

El impulso que me trae a esta tribuna académica es continuar profundizando en esa especie de Vidas paralelas que, al estilo de Plutarco, he establecido entre la vida de don Ricardo Palma Soriano y la de su hijo mayor Clemente Palma Ramírez.

Desarrollaré en esta oportunidad, las causas que llevaron a padre e hijo -cada uno en su respectivo tiempo- al destierro en Chile, así como los acontecimientos más saltantes de los que fueron participes durante su permanencia en el país sureño y, de forma particular, lo que produjeron intelectualmente como aporte sustancial a su corpus literario.

\section{VIDA I: RICARDO PALMA}

\section{Aproximación a Chile y primeros contactos chilenos}

Contrariamente a lo que muchos podrían pensar, el primer contacto de Ricardo Palma con Chile no se dio a causa de su deportación, en 1860. Existen algunos antecedentes significativos que se remontan a principios de 1856, cuando

I Véase ADRIAZOLA SILVA, Juan Carlos. "Clemente, el primogénito de don Ricardo Palma”. En Aula Palma, n VIII, Lima, Instituto Ricardo Palma, Universidad Ricardo Palma, 2009, pp. 213-234; y "Ricardo Palma y sus relaciones paterno-filiales”. En Aula Palma, n X, Lima, Instituto Ricardo Palma, Universidad Ricardo Palma 2011, pp. 239-271. 
el joven Palma, siendo Oficial $3^{\circ}$ del Cuerpo Político de la Armada, asume el cargo de Contador del vapor de guerra "Loa". Es así como se da el primer contacto geográfico con la antigua tierra de los mapuches con la cual el Perú republicano no tenía frontera ${ }^{2}$. En efecto, para embarcarse en el vapor "Loa" fue necesario trasladarse al puerto de Arica, lo que le permitió luego llegar en visitas esporádicas a las ciudades-puerto que se hallaban en la costa chilena: Iquique, Caldera, Coquimbo y Valparaíso ${ }^{3}$. En donde, de seguro, pudo formarse un concepto general de esos lugares y conocer algo la idiosincrasia de su gente.

Aparte de sus tareas administrativas o contables en la Marina de Guerra del Perú, Palma seguía perfeccionando cada día más sus dotes de escritor, mediante la lectura intensa de los grandes maestros de la lengua española. Asimismo, se daba tiempo para concurrir a salones y tertulias literarias, y visitar la Biblioteca Pública Nacional ${ }^{4}$, en donde hizo buenas migas con varios intelectuales y pro hombres de la República, además de algunos personajes foráneos que, de cuando en cuando venían a la capital peruana a investigar el pasado histórico o a buscar derroteros bibliográficos sobre lo que se había producido desde antiguo en las letras peruanas. Uno de esos asiduos investigadores era el Ministro Plenipotenciario de Chile acreditado ante el gobierno peruano, don Francisco Solano

2 Recuérdese que en 1860 la frontera sur del Perú era con la República de Bolivia. Como consecuencia de la Guerra del Pacífico recién el país tendrá frontera con la República de Chile.

3 Cfr. ZUÑIGA SEGURA, Carlos. Ricardo Palma en la Marina. Lima, Editorial de la Universidad Ricardo Palma, 2004, p.41.

4 Con este nombre se registra dicho establecimiento público en la calle de Estudios (hoy cuarta cuadra del jirón Ucayali). Véase FUENTES, ManuelAtanasio. Guía del viajero en Lima. Lima, Librería Central, 1860, p.108 [Edición Facsimilar]. (+La Ciudad de los Reyes, estudio preliminar de César Coloma Porcari) Lima, Instituto Latinoamericano de Cultura y desarrollo, 1998. 
Astaburuaga Cienfuegos (21/7/1817 - 13/6/1892). Respecto a la entrañable amistad que entabló Palma con Astaburuaga, el historiador talquino Guillermo Feliú Cruz dice:

Palma le había conocido en la Biblioteca Nacional limeña a donde ambos se reunían con frecuencia. Astaburuaga hacía copiar en ese establecimiento el manuscrito de la Historia de Chile del cronista colonial Pedro de Córdova y Figueroa, cuyo traslado personalmente revisaba; y el escritor peruano proseguía sus estudios históricos sobre la época virreinal, que serían la base de sus mejores tradiciones de más tarde ${ }^{5}$.

\section{Los avatares políticos del impetuoso Ricardo Palma}

Palma que desde su temprana juventud había abrazado ideológicamente el liberalismo, así como la masonería ${ }^{6}$, fue, en consecuencia, un seguidor de quien era entonces uno de los exponentes máximos de esas dos tendencias en el Perú: el doctor José Gálvez Egusquiza․ Gálvez encabezó por aquellos días un movimiento contra el presidente Ramón Castilla ${ }^{8}$, que se concretó en una insurrección la madrugada del 23 de noviembre

5 Cfr. FELIÚ CRUZ, Guillermo. En torno a Ricardo Palma. Santiago de Chile, Prensas de la Universidad de Chile, 1933, t. I, p.61.

6 HARTH BEDOYA, Alfonso. Ricardo Palma el egregio tradicionalista e ilustre masón peruano. Lima, Editorial San Marcos, 1992, p.36.

7 Personaje que sería más tarde Secretario de Guerra y Marina, y, finalmente, cuando España hizo el intento por última vez de recuperar sus colonias en América, héroe en tierra del combate naval del 2 de mayo de 1869.

8 Según ha quedado registrado en la historia, el triunfo de la batalla de La Palma (1855) que elevó al mariscal Ramón Castilla a la Presidencia de la República, había contado inicialmente con el respaldo de los liberales, con quienes se comprometió a realizar cambios radicales en la forma de hacer gobierno en el Perú. Posteriormente, Castilla se apartaría de ellos y vino entonces la discordia y el enfrentamiento. Véase BASADRE, Jorge. Historia de la República del Perú 1822-1933. Lima, Editorial Universitaria, S.A., 1970, t. IV, cap. XLVII, pp.114-116. 
de 1860, y contó con la adhesión entusiasta del joven Palma, al punto de asumir la tarea importantísima de comunicar por telégrafo a los amotinados del Callao el momento del ataque para su correspondiente intervención, secundando el movimiento de la capital. La oportuna intervención del coronel Pablo Arguedas que vivía frente a la casa de Castilla en la calle de las Divorciadas (hoy cuadra 6 del jirón Carabaya) y la rapidez con la que actuó la mujer del Presidente, doña Francisca Diez-Canseco', quien ayudó a su marido a huir apenas con la ropa interior, por los techos de la casa, abortó la conspiración y derrotó a la fuerza sublevada. El saldo final sumó 6 muertos y 4 heridos $^{10}$.

Al fracasar el plan, los conjurados huyen despavoridos y los cabecillas se ven obligados a buscar asilo político en las legaciones de Francia (Enrique Lara), Inglaterra (Pedro José Saavedra) y Chile. A esta última representación (ubicaba entonces en el antiguo Palacio de Torre Tagle), llegan presurosos: José Gálvez, Manuel María Rivas, Benigno Madueño y Manuel Moreno. El presidente Castilla estaba dispuesto a castigar severamente a los conspiradores liberales, y ordena a su Ministro de Relaciones Exteriores, José Fabio Melgar, que mediante intercambio de notas diplomáticas se tomen las medidas necesarias con los agentes de las legaciones involucradas para que los causantes del atentado contra el Gobierno y hacia su persona no saliesen impunemente del país, pues se les debía considerar como "delincuentes de atroces delitos de reos comunes"11. Ante esta presión del gobierno peruano, y su peculiar forma de entender

9 Doña Francisca Diez-Canseco y Corbacho de Castilla, era una mujer de gran temple y decisión, y su intervención en el desenlace de los acontecimientos de la madrugada del 23 de noviembre de 1860 fue decisiva. Cfr. VEGAS GARCÍA, Ricardo. Las presidentas del Perú. Lima, Fondo Editorial de la Biblioteca Nacional del Perú, 2002, p.122.

10 Cfr. HOlguin CALlO, Oswaldo. Tiempos de infancia y de bohemia. Lima, Fondo Editorial PUCP, 1994, p.635.

11 Cfr. FELIÚ CRUZ. op. cit., p.68. 
el asilo diplomático, el Ministro de Relaciones Exteriores de Chile Antonio Varas de la Barra tuvo una posición muy firme de protección de los asilados peruanos.

Luego del atentado, Ricardo Palma logró pasar inadvertido por algunas semanas, pero ante el edicto de la Justicia Militar que lo solicitaba de grado o fuerza, se vio obligado a recurrir también a la protección de su antiguo amigo, el ministro chileno don Francisco Solano Astaburuaga, asilándose de inmediato en la legación de ese país del 16 hasta el 20 de diciembre de aquel año. Para el joven Palma los días de asilado político fueron de mucha preocupación y zozobra. Era un hombre de escasos recursos económicos que vivía solo de su producción periodística -la cual era política más que noticiosa o informativa, ${ }^{12}-\mathrm{y}$ de lo que el estro poético le dictaba y las piezas teatrales que componía ${ }^{13}$. Ricardo habitaba con su padre Pedro Palma Castañeda, quien frisaba los 58 años de edad, y para entonces ya llevaba muchos años separado de su legítima esposa Dominga Soriano Carrillo, quien vivía en casa aparte, quizá con su madre y hermana, en algún punto de la capital ${ }^{14}$.

Al partir el joven poeta agradece mucho las atenciones y el apoyo que recibe de los miembros de la representación chilena,

12 En su adolescencia Ricardo Palma, por influencia de su padre, fue seguidor del general Andrés de Santa Cruz, creador de la Confederación Perú Boliviana. En su juventud se convirtió en un devoto del general Manuel Ignacio de Vivanco. Por tanto, como periodista, en esos años, fue siempre detractor del general José Rufino Echenique y del general Ramón Castilla.

13 En esta época Ricardo Palma aún no descollaba en la prosa como tradicionista. Eso sería más tarde con la publicación de sus primeras Tradiciones, cuya primera serie data de 1872 .

14 De acuerdo a la investigación de Holguín, quien ha exhumado la partida de defunción de la madre del tradicionista, esta murió a la edad de 50 años a fines de 1863. La invitación para sus funerales la hizo solo su madre y hermana. Cfr. HOLGUIN CALLO, Oswaldo. Tiempos de infancia y de bohemia. Lima, Fondo Editorial PUCP, 1994, p.44. y p.47. 
especialmente del Segundo Secretario de la legación, el joven intelectual liberal Ruperto Murillo Sotomayor, quien escribió a su padre José Ramón Murillo Zeguel, administrador de la Aduana de Valparaíso, una carta de recomendación para que lo cobijara los primeros días de su llegada ${ }^{15}$. Asimismo, Palma deja como recuerdo, en el álbum de doña María del Rosario Vergara Rencoret de Astaburuaga, un poema improvisado de 32 versos titulado: "Al partir para el destierro"; en los principales versos se lee:
$\mathrm{Al}$ arpa del proscrito
pedís una armonía;
al ave que se aleja
pedís una canción;
queréis que exhale en versos
la desventura mía
y que hasta voz levante
mi humilde inspiración.

En medio de la amargura

que me brindó el destino, cuando busqué el asilo que ha vuestro lado hallé cuando al dejar la patria, doliente peregrino, pensé que a perder iba mi espíritu su fe ${ }^{16}$.

A las cuatro de la tarde del día 20 de diciembre, acompañado del brazo por el ministro Astaburuaga, el conspirador desterrado se

15 Cfr. PAlMA, Angélica. Ricardo Palma [Edición del centenario del Tradicionista (7 de febrero de 1993) con numerosas ilustraciones documentales] Buenos Aires, Ediciones Argentinas “Cóndor”, 1933, p.42.

16 Véase texto completo del poema en FELIÚ CRUZ... op.cit., t.II, pp.267-268. 
embarca en el vapor inglés "Lima"17, que lo llevará del Callao a Valparaíso. En esta circunstancia dolorosa, quizá ya dentro del barco, se dio tiempo para escribir el poema "Navegando", el cual contiene versos de una fuerte carga emocional que rezan así:

Parto ioh, patria! desterrado...

De tu cielo arrebolado

Mis miradas van en pos;

Y en la estela

Que riela

Sobre la faz de los mares,

iAy! Envío a mis hogares

un adiós.

iPatria! iPatria! Mi destino

Me arrebata peregrino

Y para siempre quizás...

Si desmaya

En otra playa

Mi varonil ardimiento,

Mi postrero pensamiento

Tú serás... ${ }^{18}$

\section{El ambiente politico chileno}

A similitud de lo que ocurría con los desterrados políticos ecuatorianos que veían al Perú, y más específicamente a la

17 Este dato del vapor "Lima" lo consigna documentalmente: HOLGUíN CALLO... op. cit., p.642. Autores como Guillermo Feliú Cruz...op.cit., t. I, p.89 y José Miguel Oviedo. Genio y figura de Ricardo Palma. Buenos Aires, Editorial Universitaria de Buenos Aires, 1965, p.62 señalan, sin embargo, que Palma se embarcó en un vapor de nombre "Florida". No dan ninguna referencia documental para su aseveración.

18 Cfr. FELIÚ CRUZ... op.cit., t. I., p.88. 
ciudad-puerto de Paita (en Piura), como el lugar cercano donde recalar y tener la oportunidad de una paciente espera que los retornase algún día a la patria ${ }^{19}$, así también muchos desterrados políticos peruanos veían a Chile y a la ciudadpuerto de Valparaíso como el lugar idóneo para esperar mejores tiempos. Como a los demás asilados del ministro Astaburuaga, a Palma se le recomendó encarecidamente, de acuerdo a la neutralidad que estipulaba el "derecho de asilo", no emitir opiniones políticas y menos aún intervenir en actividades proselitistas mientras estuviera asilado en el territorio chileno.

En Chile gobernaba entonces el presidente Manuel Francisco Antonio Julián Montt Torres (Petorca 1809 - Santiago 1880), quien se hallaba en el Poder gracias a una reelección para un segundo período de gobierno (1851-1856/1856-1861), y era considerado, en líneas generales, como un político de derecha. Abogado de profesión, profesor universitario, diputado, varias veces ministro de Estado, llegó a presidir la Corte Suprema. Con su gobierno se inició la etapa de presidentes civiles de su país. Se le consideraba como el verdadero organizador de la República, siguiendo las ideas que años antes propuso Diego Portales. Montt, de acuerdo al concepto de sus gobernados, era despiadado y oprobioso para sus opositores; y fuerte, centralizador y ordenado, para sus seguidores.

En lo económico, el decenio de Montt presentó un decisivo crecimiento basado en la producción y exportación de cobre, lo que fortaleció las finanzas públicas. Esto permitió la fundación

19 En aquellos años (mediados del siglo XIX) el puerto de Paita estaba muy relacionado con el Ecuador: era la población a donde iban a parar los emigrados y desterrados en las luchas políticas; el centro donde se reunían los conciliábulos de conspiradores de uno u otro partido, donde se fraguaban las revoluciones contra los gobiernos del Norte. Cfr. VILLALBA, Jorge. Manuela Sáenz / Epistolario. Quito, Ediciones del Banco Central del Ecuador, 1986, p.65. 
del Observatorio Astronómico, la creación de escuelas primarias y liceos en varias ciudades. Asimismo, comenzaron los trabajos de los edificios del Congreso Nacional y de la Casa de Orates, la Escuela Normal de Preceptoras de Santiago en 1853, y la aprobación de la Ley de Instrucción Primaria impulsada por Antonio Varas.

El crecimiento en la minería permitió el surgimiento de las grandes fortunas chilenas, lo que influyó en la conformación de nuevas sociedades de capitales, asociadas a las extranjeras, para la construcción de edificios de aduanas en varios puertos, la adopción del alumbrado público por gas y, sobre todo, la construcción de las líneas de ferrocarriles que unieron al país. Sin embargo, este mandato no estuvo exento de problemas: hubo discrepancias con el Parlamento, y en 1859 estalló una revolución en diferentes regiones del país, exigiendo reformas a la Constitución de 1833.

Luego del presidente Montt vendría el gobierno del presidente José Joaquín Pérez Mascayano (Santiago de Chile 18011889), quien bajo la bandera del Partido Liberal estableció un gobierno de centro derecha (18/9/1861- 18/9/1871). Subió al poder apoyado por todos los partidos y todas las personas que ansiaban tranquilidad después de las agitaciones de la Guerra Civil de 1859.

Este es el panorama político que, en líneas generales, encontraría Palma a su arribo a Valparaíso, el cual se produjo el 28 de diciembre de $1860^{20}$.

20 Cfr. PALMA, Ricardo. Epistolario general. Lima, Editorial Universitaria, Universidad Ricardo Palma, 2005, t. I, p. 57. 


\section{¿Cómo era Valparaíso al arribo de Palma?}

Valparaíso era una ciudad-puerto en donde el relieve terrestre tenía dos planos claramente diferenciados: la parte llana cercana a la playa, estaba habitada por la gente más humilde y vinculada a las faenas de la pesca u otros comercios; la parte elevada de los cerros, la ocupaban la gente de mejores recursos y las hermosas casas que allí predominaban tenían vista al mar. Los cerros eran abundantes, más de cuarenta y dos, y era la zona en donde se ubicaba el centro histórico y los barrios más elegantes. Dignos de mencionar son los Cerros Concepción, Bellavista, Delicias, Florida, O`Higgins, Arrayan, Carretas, Panteón, La Loma, San Francisco y, especialmente, Alegre, en donde vivió Ricardo Palma en una humilde pensión durante su destierro. Guillermo Feliú nos aproxima al paisaje valpino con las siguientes pinceladas:

La planta de la ciudad, todavía estrecha, con un sabor de puerto cosmopolita, presenta al viajero una sensación abigarrada. En él era fácil advertir el origen español de sus casonas, de sus iglesias de construcción maciza, de sus amplios conventos opulentos. La plaza de la Intendencia, el muelle, los balcones, descuidados y sucios, no indicaba una administración eficiente. Las casas chatas apretujadas, resaltaban por los colores chillones de sus pinturas. Alrededor de la playa, un hampa de hombres y mujeres, se confundían con los cargadores bronceados y soeces, rudos y fortachos (...) Hacia los cerros la visión cambiaba. Las construcciones tenían otro carácter y daba la impresión de haber sido levantados por hombres de más ágil pensamiento, que tenían de la vida un sentido de comodidad y confort. Eran las residencias inglesas, francesas o norteamericanas. Se habían retirado del estrecho plano, un poco ingrato, para anidar sus hogares en los propicios contrafuertes cerriles ${ }^{21}$.

21 Cfr. FELIU CRUZ, Guillermo. Discurso en "Homenaje de la Biblioteca Nacional de Chile a la memoria de Ricardo Palma" 7/2/1933. En Ricardo 


\section{Colegas escritores y amigos chilenos de Palma}

El carácter sencillo y don de gentes que transmitía la personalidad de Palma, le granjeó pronto el aprecio y la permanente invitación de los círculos culturales y sociales tanto valpinos como santiaguinos, así como de algunos cenáculos literarios en ciudades cercanas como La Serena ${ }^{22}$ y otras, en donde siempre fue foco de atención por su ingenio, donosura y modales gentiles. Larga es la lista de los hombres de letras que lo trataron entonces con llaneza y con quienes guardaría en el futuro estrecha vinculación epistolar: Guillermo Matta, Benjamín Vicuña Mackenna, José Victoriano Lastarria, Diego Barrios Arana, los hermanos Miguel Luis y Gregorio Víctor Amunátegui Aldunate, Guillermo, Alberto y Joaquín Blest Gana, Ambrosio Montt Luco, Eduardo de la Barra Lastarria, Zorababel Rodríguez Benavides, Vicente Aguirre Vargas, Ventura Blanco Viel, Máximo Ramón Lira Donoso, Rómulo Mandiola Muñoz, Carlos Walker Martínez, Enrique Nercasseux y Morán, Justo Molina, Luis Felipe Prieto del Río, Rafael Gumucio, Crescente Errázuriz, Ramón Subercaseaux, Esteban Muñoz Donoso, Pedro N. Cruz, Miguel Cruchaga, Francisco A. Concha Castillo, Adolfo Valderrama, Enrique del Solar, José Antonio Soffia, Augusto Orrego Luco, Francisco de Paula Taforó, Víctor Torres Arce y Manuel Concha Gajardo. En esos círculos tampoco faltaron las literatas, tal es el caso de: Mercedes Marín del Solar, Lucrecia Undurraga Solar, Eva Cousiño, las hermanas Regina y Ángela Uribe Orrego, y otras figuras descollantes de la intelectualidad chilena, además de algunos extranjeros, como el argentino Gregorio Beeche Estévez, según concepto de Palma, “el más entendido y curioso

Palmal833-1933 (Libro conmemorativo por el primer centenario de su nacimiento). Lima, Sociedad Amigos de Palma, 1934, pp.197-198.

22 Cfr. PALMA, Ricardo. Epistolario general. Lima, Editorial Universitaria, Universidad Ricardo Palma, 2005, t. I, pp. 54, 56 y 63. 
bibliófilo de América"23, y el boliviano Gabriel René Moreno del Rivero que por entonces vivía también en Valparaíso.

\section{De sus escritos y talentos ha de procurarse el pan en tierra extraña ${ }^{24}$}

Para ganar el sustento diario, Palma debe trabajar en lo que mejor sabe hacer: escribir. Y sus primeras colaboraciones las encontramos en la Revista de Sud América, órgano de la Sociedad Amigos de la Ilustración. En esta publicación, dirigida por Juan Ramón Muñoz (1860 - 1864) el escritor peruano comenzó como simple colaborador y concluyó como redactor principal. Es interesante destacar, además, que Palma en la Revista de Sud América no olvidó comentar y promocionar permanentemente a sus colegas líricos del Perú, a través de una serie de artículos que englobó en la sección "Poetas peruanos". Tal honor merecieron, por ejemplo: "Manuel Segura, poeta cómico", "Don Carlos Augusto Salaverry, poeta dramático", "Manuel Adolfo García", "Don Manuel Castillo", "Don José Arnaldo Márquez", "Delirios de un loco. Colección de poesías de don Ángel Fernando Quiroz", "Cánticos del Nuevo Mundo, poesías de Fernando Velarde, estudio crítico" 25 .

Con el destierro a Chile, Palma no cortó tampoco el cordón umbilical que lo unía a una publicación peruana, de la cual era muy afecto: La Revista de Lima, quincenal de cuarenta y

23 Loc. cit., p.42.

24 Cfr. Es una expresión que se encuentra en la carta de recomendación a Palma que el ministro Astaburuaga dirige a doña Rosario Orrego redactada en Lima y fechada el 20 de diciembre de 1860. Cfr. En FELIÚ...op.cit., t.I, cap. II, p.91.

25 Cfr. PALMA, Ricardo. En Revista de Sud América. Valparaíso, 1861, t.I, pp.393, 537, 612, 662, 713; 1861, t.II, pp.148 y 315. Véase además PALMA, Epistolario general, t.I, p.41. 
ocho páginas, que al igual de lo que fue el Mercurio Peruano a fines del siglo XVIII, era la publicación más representativa de la inteligencia peruana de la época. La Revista de Lima fue creada el 1 de octubre de 1859 por José Antonio de Lavalle y una pléyade de escritores y hombres de ciencia, entre los que se encontraban: Toribio Pacheco, Ignacio Novoa, Juan Vicente Camacho, Luis Benjamín Cisneros, Felipe Masías, Mariano Álvarez, Francisco Laso, Manuel, José y Felipe Pardo y Aliaga, y Juana Manuela Gorriti. Palma, según diversas cartas dirigidas a José Casimiro Ulloa, director de la publicación ${ }^{26}$, solicitó constantemente diversos números de La Revista de Lima para obsequiarlos a intelectuales valpinos y santiaguinos, con quienes se relacionaba en los salones literarios o canjeaba con otras publicaciones chilenas de su interés. Además, él había asumido la responsabilidad de ser vendedor de sus suscripciones en el país sureño ${ }^{27}$.

Un asunto interesante que debe destacarse respecto a la situación económica que afectaba a los deportados políticos que participaron directamente en el atentado contra la casa del presidente Castilla, se refiere a la ayuda solidaria que, a modo de subvención, les remitían, aunque no quizá periódicamente, sí intermitentemente, desde Lima sus colegas liberales, con el propósito de palear en algo sus necesidades básicas. Esta información se desprende de una de las cartas que don Ricardo le remitió al director de la Revista de Lima, José Casimiro Ulloa, en la que leemos:

En el mes de Agosto no hemos recibido la subvención que nos envían de Lima o por lo menos Madueño cuyas circunstancias

26 Palma al retornar del destierro chileno asumió con Juan Vicente Camacho la dirección de La Revista de Lima, en 1863, y debieron explicar las razones de su desaparición tiempo después.

27 Cfr. PALMA, Ricardo. Epistolario... t.I, p.44. 
son apuradísimas no nos ha dicho nada. Reserve V. esto y no haga uso de ello. En verdad, amigo, que es muy deliciosa la vida de los proscritos sobre todo cuando la bolsa está escueta ${ }^{28}$.

Palma y sus amigos de conspiración no fueron los únicos desterrados políticos peruanos que se encontraban en Chile. Mucho antes habían arribado, su viejo amigo el general Manuel Ignacio de Vivanco ${ }^{29}$ y el ex presidente del Perú, general José Rufino Echenique; a este último, incluso, Palma escribió, seguramente para agenciarse recursos económicos más que por convicción política, un extenso manifiesto ${ }^{30}$ en contra de las tropelías del mariscal Ramón Castilla.

\section{Exilio e ideal de unidad americana}

Dos años durará el exilio de Palma en las tierras del Mapocho; tiempo éste que será intenso y fructífero por una serie de acontecimientos que lo afectarán. Las primeras puertas de los contactos personales las abren las cartas de recomendación que en Lima le había entregado el ministro chileno Astaburuaga: una, dirigida al periodista boliviano desterrado también en Chile Juan Ramón Muñoz Cabrera y, la otra, para la connotada poeta Rosario Orrego de Uribe ${ }^{31}$. En salón literario valpino de

28 Cfr. Carta de Ricardo Palma a José Casimiro Ulloa redactada en Valparaíso el 2 de setiembre de 1861. Epistolario general, t. I, p.47.

29 Loc. cit., Valparaíso 17 de julio de 1861, p.39.

30 El manifiesto se titula: "Los Hechos. Exposición que dirige a los pueblos del Perú José Rufino Echenique”. Fue impreso en Valparaíso en la Imprenta del Universo de G. Helfmann, 1861. Cfr. FELIÚ... op. cit., t.II, p.19.Véase Riva Agüero, José de la... “D. Ricardo Palma”. En Mercurio Peruano, enero 1919, Año II, vol. IV, n'19, p.12.

31 En agradecimiento a esta poeta, Palma, entre otras finezas, escribiría un prólogo a la novela de costumbres que ella publicó bajo el título de: Alberto el Jugador, editada en Valparaíso, que lleva fecha 28 de octubre de 1861. Véase: FELIÚ CRUZ... op. cit., t. II, pp.14-19. 
la señora Uribe conoció a las personalidades más altas de las letras y la sociedad chilena, entre ellos a Guillermo Blest Gana, director de la Revista del Pacífico, y a Vicuña Mackenna, con quien lo unió desde entonces una larga y sincera amistad.

Palma se ve envuelto pronto en una polémica periodística a propósito de las ambiciones de la reina Isabel II de España, quien desea recuperar las colonias americanas e intervenir directamente a México. En Chile, Ricardo Palma fue el primero en iniciar la campaña americanista en contra de los despropósitos españoles con un artículo titulado "La Reconquista" que llevó a la imprenta de El Mercurio de Valparaíso, cuyo propietario, José Santos Tornero, español de nacimiento, se negó a publicarlo por considerarlo exagerado y violento contra la monarquía ibérica; Palma lo denunció en una hoja volante, bajo el seudónimo masónico de "Pablo.: Job.:" Finalmente, la Revista de Sud América aceptó publicarlo, pero a condición de que usara un tono más mesurado.

La posición adoptada por Palma sobre la unidad americana, no era una posición antojadiza, obedecía más bien a un ideal superior: la unidad de la raza, de la lengua y de los anhelos democráticos comunes. El sueño de Bolívar estaba redivivo en ellos. Y es en Valparaíso donde funda, en compañía del general Ramón Dehesa, el poeta chileno José Antonio Torres y el boliviano Juan Ramón Muñoz, "La Unión Americana: Sociedad de Republicanos". La Sociedad inició una labor de propaganda americanista que en esos instantes de lucha e inquietudes fratricidas era oportuno recordar. Ellos, sus miembros y sus prosélitos, en la prensa, en los meetings, en la tribuna académica y forense, donde quiera que fuese, hablaron de la necesidad de mancomunar esfuerzos, para avivar ideales, de levantar los grandes recuerdos de la jornada heroica de la Independencia que fue la obra colectiva de un solo anhelo desde el Río Grande hasta la lejana y remota isla de Chiloé. 


\section{El nostálgico efluvio de su lírica y el origen de sus Armonías. Libro de un desterrado}

Antes que la prosa, la experiencia creadora de Palma desde su adolescencia había sido la poesía. Campo en el que llegó a ser un versificador notable, según puede apreciarse en sus primeros trabajos que con los años han ido descubriéndose en las páginas de periódicos y revistas limeñas que corresponden a los tiempos de la bohemia romántica ${ }^{32}$. Este bagaje le acompañó también durante su deportación chilena. Se ganó el sustento escribiendo para muchas de las publicaciones valpinos y santiaguinas interesadas en recibir sus colaboraciones. Esta producción quedó recogida de forma compendiosa en un libro que lleva por título: Armonías ${ }^{33}$. Libro de un desterrado político. Este poemario se editó en París de forma completa, en $1865^{34}$, cuando Palma se encontraba ya en el Perú dos años después de haber retornado de Chile. Para el prólogo, escogió un texto de su amigo colombiano José María Torres Caicedo que le pareció oportunísimo para su obra ${ }^{35}$. El poemario Armonías. Libro de un desterrado, se abre con estos versos elocuentes:
Amores y esperanzas
ensueños y alegrías
del patriotismo arranques
y notas de aflicción;
pues fuiste de mis horas

32 Los periódicos y revistas literarias en las que se encuentran las primeras producciones poéticas de Palma se remontan a 1848 en adelante, y son: "El Diablo", "El Correo", "El Burro", "El Liberal", "El Diario", etc.

33 Armonías es en la producción poética palmina un nombre recurrente pues se halla en diversos trabajos publicados en periódicos y revistas chilenas en los que el tradicionista colaboró entre 1861-1863.

34 Este poemario fue editado por la Librería de la viuda de Ch. Bouret. París, Rue Visconti, 23; según dato que ofrece Feliú Cruz en la op.cit., t. II, p.44.

35 Cfr. Loc.cit. p.44. 
constantes armonías,

vivid en este libro

carísimos efluvios, flores del corazón! ${ }^{36}$

En total el libro en referencia recoge casi un centenar de poemas de excelente factura, todos publicados en periódicos y revistas de Valparaíso y Santiago. Las composiciones poéticas son: Efluvios del corazón / Navegando: 20 de diciembre de 1860 / A Guillermo Matta / Aura /Misterio / A una flor / Tus ojos / Lamento /llusiones / El juzgamiento de Cristo /A mi amigo Abigail Lozano /Nocturno /Secreto /Serenata /Nostaljia (sic) / Esperanza: a Cristina Bustamante / Fragilidad / Las ánimas / Peregrina / Amor / Duende / Traducción de Víctor Hugo / Claro-oscuro / Indignación / Italia / Marcó /Pasionaria /Mejor es creer / Constancia / A cuatro hermanas / Oriental [versión A] / Camino del cielo / Antifaz / Tristeza / Brindis [versión A] / La Conciencia / Víctor Hugo / La leyenda de los siglos / Ave de paso/ Oración fúnebre / Meteodoro / Confrontaciones /Chatiments: Traducción de Víctor Hugo / Vaguedad / En la noche / Cantinela / Todo se olvida / La democracia: a Lorenzo García / La palabra de pase de la vida / Café!!! / Paseo / Mentiras del corazón / Romance / Quimera / Bacanal / Empeño / Inocencia / Intuición / Escusa / Lágrimas / Consuelo / A un traidor / Siempre joven: 7 de febrero de 1862 / En un retrato / Realidad / Hostia / Adelante / Billete / Rayo de luna / El Siglo de Oro / Connubio / Voz del alma/ Oriental [versión B]/Similia Similibus / Una hoja más / Envidia /A solas / Esperanza en Dios / Efusión / A Heraclio Fajardo / A una artista/ Melancolía /Flores y abrojos /La perla / Sarcasmo / Por qué cantas? / Contraste / Date Lillia / Amalia / Flor andina/Julio Arboleda / Hoja de laurel /En la tumba de Alfredo de Musset / Venecia / Voz íntima (Aflixión íntima) a Luis Benjamín Cisneros / Mlle. Genoveva Charny / Filosofía

36 Cfr. Loc.cit. p.45. 
[versión A] / A Laura Ascasubi / El cubil de la fiera /Nomen, Numen, Lumen.

A este grupo de composiciones líricas. Palma creyó conveniente agregar, como apéndice a Armonías. Libro de un desterrado, otro conjunto de poemas suyos, escritos no en Chile sino en Lima, que llevaban por título Cantarcillos, inspirados en la obra del poeta vizcaíno Antonio María de Trueba y de la Quintana (1809-1819) autor del Libro de los Cantares editado en 1852. En el prólogo de los Cantarcillos, Palma explica a sus lectores el origen de estos poemas populares:

En una época bastante azarosa para mi patria, publiqué anónimos en un diario de Lima varios Cantarcillos, sirviéndome de tema para ello los versos que en mi infancia había recogido de ese gran poeta que se llama pueblo. (...) Mi excelente amigo, el bardo venezolano don Juan Vicente Camacho, me alentó con su aplauso a cultivar la musa popular, y a que considerase esas composiciones como apéndice de las Armonías. Muchos versos he condenado a la hoguera, y acaso habría hecho bien en dar igual destino a todos los que han salido de mi péñola; pero si no me engaña el amor de padre con los hijos más deformes, hay en los cantarcillos merecimientos para salvarse de las llamas y tener la vida del libro $^{37}$.

Los Cantarcillos comprenden las siguientes composiciones: Vanidades / Amor interesado/Mala correspondencia / Paciencia y barajar / promesas dulces / Vivir muriendo / Desaires / Pretensión exajerada (sic) / Eres turco y no te creo / Poco falta / Non plus ultra/La gran noticia / Bienes y males/Transmigración / Te conozco /Emma.

37 Palma, Ricardo cit. por Feliú Cruz, op.cit., t.II, p.47. 


\section{Lo mejor de su prosa en Chile: Anales de la Inquisición de Lima}

Varios estudiosos de la obra palmina han coincidido en que lo mejor de la prosa de Palma durante su estadía chilena es Anales de la Inquisición de Lima ${ }^{38}$. Conjunto de relatos de acontecimientos y personajes, vinculados a determinados casos que constituyeron materia de procesos del Tribunal del Santo Oficio limeño durante la época virreinal, y que fueron tratados por Palma con el gracejo y el estilo chispeante que le caracterizó. El citado Feliú dice:

Palma nos introduce discretamente en el tremendo Tribunal para hacernos conocer sus procedimientos y artimañas. La obra fue, sin duda, una revelación, y para el tiempo en que se produjo, cuando los ultramontanos de la escuela francesa hacían su agosto en América, no pudo haber mejor y más espléndido argumento, que los hechos escuetos, fríos, y exactos presentados por Palma. Había una intención anticlerical en esas páginas, velada, es cierto, pero profundamente certera ${ }^{39}$.

En el extenso prólogo de Anales de la Inquisición de Lima, de 1997, redactado por el antropólogo e historiador Luis Millones Santagadea, se lee:

38 Gracias a la labor editorial del Congreso de la República del Perú iniciada en 1997, los palmistas peruanos y extranjeros han podido conocer, luego de un siglo exactamente, una cuarta edición ampliada y facsimilar de Anales de la Inquisición de Lima, la cual se reeditó en base a la tercera edición que Ricardo Palma mandó imprimir recién en 1897, en el Establecimiento Tipográfico de Ricardo Fé, en Madrid.

39 Cfr. FELIU CRUZ, Guillermo. Discurso en "Homenaje de la Biblioteca Nacional de Chile a la memoria de Ricardo Palma” 7/2/1933. En Ricardo Palma1833-1933... p.199. 
En alguna fecha imprecisa, entre 1860 y 1863, quizá en su modesta pensión de Cerro Alegre (Valparaíso), Ricardo Palma escribió los originales de lo que más tarde sería Anales de la Inquisición de Lima. No es el primer exilio productivo para los pensadores peruanos: Chile ha sido en más de una ocasión ([tal es el caso de] Luis A. Sánchez, Ciro Alegría, etc.) el espacio providencial para obras de envergadura ${ }^{40}$.

Al salir expatriado a Chile Palma no partió con las manos vacías; como parte de su ligero equipaje llevó consigo algunos cuadernos conteniendo valiosos apuntes que le servirían para componer una serie de relatos que denominó Anales de la Inquisición de Lima. Conjunto de sabrosas narraciones que publicó por entregas en la Revista de Sud América de Valparaíso, la Revista del Pacífico, la Revista del Paraná y al mismo tiempo fue enviando al Perú a La Revista de Lima. Aquellos apuntes a los que se ha hecho referencia los tomó Palma de la Biblioteca y Archivo Nacional de Lima, desde antes de la Guerra del Pacífico, esto es, desde antes de que la soldadesca chilena ocupara la capital peruana, expoliara sus repositorios y trasladara esos fondos documentales a la Biblioteca y Archivo Nacional de Santiago de Chile en $1890^{41}$,

40 Cfr. PALMA, Ricardo. Anales de la Inquisición de Lima. Prólogo de Luis Millones. Lima, Ediciones del Congreso de la República, 1997, p.vii.

41 Ha habido varias tentativas oficiales en el gobierno peruano por tratar de recuperar los libros y los antiguos documentos que pertenecieron a la Biblioteca y Archivo Nacional de Lima expoliados durante la Guerra con Chile a partir de 1879. Solo se ha podido recuperar una ínfima parte de los libros, pero sobre los volúmenes que contienen los procesos inquisitoriales, las tentativas han sido infructuosas hasta el 2013. Se estima que los más de 500 volúmenes conteniendo los procesos judiciales que se hallan en el actual Archivo Nacional de Santiago de Chile, son en extremo valiosos para reconstruir el pasado histórico del Perú durante su época colonial. Véase: NEIRA, Hugo y LOPEZ DE CASTILLA, Irma. Después de 126 años volvieron a casa. Catálogo de los libros devueltos por Chile a la Biblioteca Nacional del Perú. Lima, Fondo Editorial de la BNP, 2007; y HAMPE, Teodoro. "Ricardo Palma cronista de la Inquisición”. En Aula Palma, n IV, Lima, Instituto Ricardo Palma, Universidad Ricardo Palma, 2003-2004, pp.145-164. 
podían ser consultados en la institución bibliotecaria fundada por el Generalísimo don José de San Martín, y que ya desde esos años eran considerados como verdaderos tesoros históricos del antiguo Virreinato del Perú.

Los escritos palminos eran indudablemente insuficientes para una historia cabal y certera del Santo Oficio limeño, y ellos debían ser completados con mayor información, tarea esta que Palma no podía realizar desde Valparaíso sino únicamente en contacto con los mismos documentos que se hallaban a más de 3,374 kilómetros de distancia. Además, los recursos económicos para solventar una posible edición valpina eran escasos en esos momentos dada su condición precaria de desterrado. He aquí las razones por las cuales Palma publicó recién este trabajo en forma de libro a su retorno a Lima, en la Imprenta de Aurelio Alfaro (Baquijano $n^{\circ}$ 317), en 1863. En carta fechada el 17 de julio de 1861, el joven tradicionista corrobora este aserto, cuando dice a su amigo limeño José Casimiro Ulloa lo siguiente:

Como sabrá V. no pierdo el tiempo en el destierro. La ociosidad y el estado del espíritu me obligan a buscar un consuelo en las letras. Me ocupo de un trabajo bastante serio y que creo será de alguna utilidad para la historia del Perú en su época de coloniage (sic). Este trabajo se titula Anales de la Inquisición de Lima y que publicaré en un tomo si Dios es servido cuando el estado de mi bolsa lo permita. En el Vapor próximo remitiré a V. para [La] Revista [de Lima] uno de sus capítulos titulado "Ángela Carrasco". Es la historia de una beata, escritora teóloga a quien la Inquisición trató de achicharrar y sobre la que habrá V. oído hablar en Lima contar mil consejas. Si le agrada ese capítulo y se resuelve a publicarlo desearía que colocara una nota de Redacción, anunciando que es parte de un extenso trabajo que me propongo terminar. Fáltame algunos datos que completaré cuando vaya a Lima, como los relativos a la causa de Francisco Moyen y tres o cuatro Autos 
de fe sobre los que deben existir documentos que espero poder consultar en mejores tiempos. Si agrada ese capítulo le enviaré otros $^{42}$.

\section{Balance favorable}

En líneas generales, la producción intelectual, periodística y literaria fue muy provechosa y el balance que arrojó fue favorable para Ricardo Palma. Según señala su nieta Edith:

La estada en Chile significó para Palma algo más que el exilio o la reflexión de una derrota triunfal de juventud. Alguna relación ofrece con la de Rubén Darío, en lo que se relaciona con la iniciación y formación literarias. Para ambos, Chile representó el ambiente más propicio, como que en aquellos tiempos -primero Palma, después para Darío- era ese pequeño país del Pacífico el más acogedor, el más inquieto para las nuevas perspectivas de la inteligencia, el más dado a las nuevas corrientes renovadoras de la pedagogía, la literatura y el arte. En Valparaíso y en la capital del Mapocho desarrolló una intensa actividad literaria, de la cual la periodística fue la peculiar de esos años de experiencia continental ${ }^{43}$.

La experiencia vivida en Chile por Palma -el conocimiento de sus instituciones organizadas y progresistas- fue la primera fase en la formación de su espíritu, así como el viaje a España en 1892, sería decisivo para la madurez definitiva del escritor.

42 Cfr. Palma... Epistolario... t.I, pp.40-41.

43 Cfr. PALMA, Ricardo. Tradiciones peruanas completas (Edición y prólogo de Edith Palma). Madrid, Aguilar, 1957, pp. xxxvii. 


\section{El tornaviaje}

Hallábase Palma en una intensa actividad cultural en Chile cuando el presidente mariscal San Román, ilustre masón y sucesor de Castilla, promulgó la ley de amnistía política y, en consecuencia, dejó a los desterrados políticos en la libertad de retornar al país; sin embargo, el tradicionista hará recién el tornaviaje al Perú en 1862. Castilla -enemigo de Palma en 1860- no le guardaba ningún rencor, porque en el fondo siempre había admirado la pluma galana y fácil de su adversario. Castilla, además, le estaba agradecido a Palma por la defensa que hizo de él en el Teatro de Valparaíso el 22/4/1862, cuando José Antonio Torres de la "Unión Americana" acusó injustamente al Presidente del Perú de tener tendencias monárquicas en el orden internacional ${ }^{44}$. Respecto a este acontecimiento, Angélica Palma expresa:

El discurso provocó aplausos y comentarios; sus ecos llegaron al Perú y, por supuesto, hasta los oídos de Castilla. -Buen muchacho... buen muchacho ese Palmita -dijo don Ramón, con su peculiar manera de cortar y repetir las frases que hasta ahora imitan los peruanos, aunque ya casi no quede sobre la tierra quien alcanzara a oírlo. -Tiene talento... y es patriota... sí... muy patriota... Yo lo quiero... pero él no me quiere a mí... no me quiere ${ }^{45}$.

44 Por largos años se ha pensado que la defensa de Palma a favor de Castilla había sido porque Torres tildó de "tirano" o "dictador" al Presidente; de haber sido así de seguro que dicha opinión no habría disgustado a Palma, pues, en el orden interno, seguía considerándolo de ese modo. Véase Epistolario general 1846-1891. T. I (Edición, prólogo, notas e índices de Miguel Ángel Rodríguez Rea). Lima, Editorial Universitaria, Universidad Ricardo Palma, 2005, nota lbis, p.75.

45 Cfr. PALMA, Angélica. Ricardo Palma [Edición del Centenario del Tradicionista (7 de febrero de 1993) con numerosas ilustraciones documentales] Buenos Aires, Ediciones Argentinas “Cóndor”, 1933, p.46. 
¿Cómo se recibió la noticia de la llegada de Palma? Al conocerse en Lima que el presidente San Román había concedido a sus antiguos amigos liberales y masones la amnistía por su participación en la conspiración del 23 de noviembre de 1860, se creó en la capital un ambiente favorable a su gobierno, por el clima de paz y sosiego político que instauraría luego de casi ocho años de férrea "dictadura castillista". En Valparaíso, Palma se embarcó en el vapor inglés "Callao", que lo trajo nuevamente a la patria, el lunes 27 de octubre de 1862, de acuerdo al anunció que El Comercio de Lima publicó en su sección "Movimiento Marítimo". Al día siguiente, el decano de la prensa nacional, en la sección "Crónica de la Capital", saludó así la llegada del treintañero y célebre Palma:

En el vapor que llegó ayer vino el señor D.R. Palma, que durante dos años ha estado comiendo el pan del proscrito en la hospitalaria tierra de Chile. El señor Palma, joven de nobles y generosos sentimientos y a quien ha cabido su parte de dolores y lágrimas en las borrascas de nuestra vida, vuelve hoy al seno de la patria precisamente cuando es más necesario el concurso de los que como él la aman de veras para consolidar la paz que felizmente es ya, no solo un hecho, sino una convicción y un sentimiento que todos abrigan ${ }^{46}$.

¿Qué afectos esperaban a Palma en Lima? Si bien para los colegas y amigos literatos y políticos la llegada de Palma a la ciudad del Rímac causaba entusiastas muestras de afecto, quien sí lo había extrañado profundamente era su padre, don Pedro, quien no había dejado de relacionarse con él de forma epistolar durante los años de la proscripción, y al cual Ricardo no dejó de remitir desde Chile modestos giros de dinero para contribuir

46 Cfr. PALMA... Epistolario..., t. I, p.82. 
en algo con la manutención del antiguo mercachifle limeño ${ }^{47}$. Lo quería verdaderamente y en la añoranza del ostracismo le compuso estos sentidos versos que tituló "Melancolía":

No es este que contemplo tu horizonte

patria infeliz á la cadena atada;

no está aquí el natal valle, ni aquí el monte

donde altiva fijóse la mirada

Las brisas de la patria aquí no orean

con su soplo mi frente enardecida,

ni alivio blando á mi congoja crean

mi padre anciano, mi gentil querida.

En la noche el apoyo de mi brazo

tu cuerpo en vano, buscará doliente...

iPobre viejo! Al herirme de rechazo,

hirió el destino tu ánimo valiente ${ }^{48}$.

Por su parte, la madre del tradicionista, doña Dominga Soriano Carrillo, que vivía en casa aparte como se ha dicho en su momento, hallábase muy enferma en la época en que Ricardo Palma retornó de Chile, a tal punto que, en los primeros días de diciembre de 1863, falleció confortada por los auxilios de la santa religión, y en compañía únicamente de su madre y hermana, según se desprende de los avisos de El Comercio que ellas mandaron publicar a partir del 10 de diciembre y días siguientes, en agradecimiento por acompañar al velatorio y entierro de su ser querido ${ }^{49}$.

47 Cfr. HOLGUIN... op. cit., pp.27-35.

48 PALMA, Ricardo. Obra poética de Ricardo Palma (compilada por Merlin Compton). Lima, Biblioteca Nacional del Perú, 2000, p.297.

49 Cfr. Ibíd., nota 115, p.47. 
A pesar de la tristeza que de seguro debió embargar íntimamente a Palma, entendía este que la vida debía seguir su curso. Retornó a sus labores administrativas en la Marina; intentó, además, vía documental, cobrar los sueldos que no le habían sido pagados durante su deportación a Chile. Pero algunos buenos amigos, guiados por un juicio más sensato, le aconsejaron que era mejor no insistir en ello, para no arruinar futuras posibilidades en cargos expectantes al servicio del Estado. Es así como el 16 de marzo de 1863 Palma presenta una solicitud al general Ministro de Guerra en la que pide:

Que conviniendo a mi derecho retirar del despacho el expediente que gira en ese ministerio sobre pago de sueldos que se me adeudan por la época de mi expatriación en Chile, se ha de dignar Ud. ordenar que me sea devuelto para los fines que me convengan ${ }^{50}$.

La prudente decisión tomada por Palma, tendría frutos tiempo después $^{51}$. En esa actitud expectante se hallaba cuando el Presidente general Juan Antonio Pezet y Rodríguez de la Piedra lo nombró, el 14 de julio de 1864, Cónsul del Perú en Belem do Pará $(\text { Brasil })^{52}$.

50 Cfr. ZUÑIGA... op. cit., p. 44.

51 En efecto, el 4 de julio de 1865 Palma fue ascendido a Comisario de Guerra y Marina y, en noviembre del mismo año, se le nombró Jefe de la Mesa de Marina en el Ministerio de Guerra. Cfr. ZUÑ̃IGA... op. cit. p.43.

52 Aunque autobiográficamente Ricardo Palma dijo siempre que el nombramiento en el Pará se lo debía a su amigo el presidente San Román, lo cierto es que fue el general Pezet quien lo designó cónsul en esa ciudad a orillas del Amazonas brasileño. Véase HOLGUIN, Oswaldo. "Palma, Cónsul en el Pará”. En Páginas sobre Ricardo Palma. Lima, Editorial Universitaria, Universidad Ricardo Palma, 2001. pp.41-80. 


\section{VIDA II: CLEMENTE PALMA}

\section{La caída de la "Patria Nueva"}

A mediados de agosto de 1930, en el Perú todo parecía marchar de forma normal y rutinaria. El Presidente Leguía gozaba entonces de su segunda reelección obtenida un año antes. Clemente Palma, diputado por Lima y director de la revista Variedades, continuaba siendo un fiel seguidor del leguiísmo. La edición $\mathrm{N}^{\circ} 1172$ de dicha publicación salió como de costumbre el 20 de agosto de aquel año. Nada ni nadie podía presagiar lo que acontecería días después: la caída del régimen de la "Patria Nueva".

El 22 de agosto, en la ciudad de Arequipa, el teniente coronel Luis M. Sánchez Cerro se subleva contra el gobierno y encabeza una revolución que hallará inmediatamente eco en la población. ${ }^{53} \mathrm{La}$ justificación doctrinaria de este pronunciamiento militar fue plasmada en un lírico documento escrito por el doctor José Luis Bustamante y Rivero, que causó hondo impacto en el país.

Mientras tanto, en Lima, Leguía intentaba desesperadamente salvar su gobierno formando un gabinete militar presidido por el general Fernando Sarmiento, que a poco fracasa por no encontrar respaldo en la oficialidad del ejército. Por otro lado, una Junta Militar de Gobierno encabezada por el general Manuel María Ponce, en coordinación con los golpistas de Arequipa, exigirá al Jefe de Estado su dimisión el día 24. Al día siguiente, Leguía abandona Palacio de Gobierno para siempre, y se dirige al Callao donde debe abordar el "Almirante Grau",

53 Cfr. BASADRE, Jorge. Historia de la República del Perú 1822-1933. Lima, Editorial Universitaria, Universidad Ricardo Palma, 1970, t. XIV, cap .CLXXXII, pp.13-15. 
que lo llevará al exilio. Pero pronto hubo de regresar, pues los golpistas impidieron que se alejara del territorio nacional. Sánchez Cerró llegó a la capital el 27 de agosto y después de desconocer a la Junta Militar, dirigida por el general Ponce, formó una nueva Junta de Gobierno de ocho miembros que él presidiría a partir de ese momento.

La población de Lima excitada al máximo por los acontecimientos revolucionarios se volcó a las calles para entregarse a toda clase de vandalismos y pillaje. Los más osados asaltaron la residencia del ex-Presidente, en donde destrozaron, quemaron y robaron criminalmente los enseres ${ }^{54}$ que habían pertenecido al hombre más poderoso del Perú, el otrora "Gigante del Pacífico" y "Padre de la Patria Nueva". El ataque y saqueo se repitió en las casas de algunos de los más destacados personajes del leguiísmo. El hogar de Clemente Palma por encontrarse en el distrito de Miraflores no fue víctima de la ferocidad e insania de la turba, como sí lo fueron las casas de otros políticos y periodistas que vivían en el centro de la capital. Aunque no por ello su vivienda dejó de sufrir algún momento apedreamiento y rotura de vidrios, lo que causó natural temor y preocupación en su familia. Conforme pasaban los días, sin embargo, el gobierno sanchecerrista intensifica las capturas y las deportaciones. El Perú entra entonces en una espiral de violencia y en un clima de zozobra política y social, que parecía haberse estado incubando por largos años de silencio.

Ante la falta de garantías, diversas personalidades del derrocado gobierno, así como directores de periódicos y revistas, se vieron obligados a pedir asilo político en las diversas legaciones diplomáticas acreditadas en Lima. Clemente Palma acudió a

54 Véase ALVAREZ CALDERÓN, María Delfina. El saqueo olvidado. Asalto a la casa de Augusto B. Leguía: 1930. Lima, Titanium Editores, 2013, pp. 91-106. 
la Embajada de Colombia junto con Emilio Sayán y Palacios, Augusto L. Rati, Guillermo Forero Franco, Eduardo Palacios y la familia Miro Quesada, pues temían ser apresados o asesinados por su antigua vinculación con el leguiísmo ${ }^{55}$.

El 16 de noviembre de 1931 la Junta Nacional de Gobierno permitió que Leguía, luego de catorce meses de martirio en el Panóptico y cuando el preso se encontraba con la salud totalmente minada, fuese trasladado al Hospital Naval de Bellavista para que se le practicase una operación quirúrgica de emergencia. Dos días después de su llegada al nosocomio, un petardista antileguiísta arrojó una carga de dinamita al hospital, pero falló en el intento de asesinar al ex-mandatario pues este se hallaba descansando en sala distinta a la que se pensaba. El estado de salud de Leguía mejorará aparentemente luego de la operación; pero la verdad es que ya nada podía hacerse por él; su cuerpo consumido por la enfermedad y la tortura apenas si pesaba 67 libras. En su testamento, dictado con provisión el 15/1/31, había dispuesto a su abogado Alfonso Benavides Loredo, la forma cómo debía ser su funeral: "modesto y sin ningún género de aparato ni ostentación"56.

Al mediodía del 6 de febrero de 1932, a la edad de 69 años, Leguía baja a la tumba con estoica resignación cristiana. Se fue del mundo terreno, no sin antes manifestar en sus "memorias", tituladas por el mismo Yo Tirano, Yo Ladrón que sabiéndose cerca de la hora postrera solo deseaba la felicidad y la grandeza del Perú, su patria amada por la cual había trabajado y desvelado mucho $^{57}$; asimismo perdonaba a todos su enemigos por el mal

55 Cfr. Informe del Ministro de Relaciones Exteriores [de Colombia] al Congreso de 1931. Bogotá, Imp. Nacional, 1931, p. 77.

56 LEGUÍA, Augusto B. Yo tirano, yo ladrón (Memorias del Presidente Leguía). Lima, Editorial “Ahora” S.A., 1934 (?), cap. XVI, p.88.

57 Ibíd., cap. III, p.24. 
que le habían causado y que su último pensamiento de este mundo estaría consagrado a sus hijos e hijas ${ }^{58}$.

La noticia del fallecimiento de Leguía causó hondo pesar en Clemente Palma, pues, a través de los años de labor conjunta, había aprendido a estimar y querer al ex-mandatario, por quien guardaba además de respeto y agradecimiento, profunda lealtad y admiración. Así quedará manifiesto tres años después, en 1935, cuando Palma escriba su opúsculo titulado Había una vez un hombre... dedicado a enaltecer la figura y la obra de Leguía, a quien llega a calificar como su "noble amigo y querido jefe" y "mártir de la religión y de la patria"59.

\section{El destierro en Chile}

Alejado completamente de Variedades, Clemente Palma tiene la intención de retirarse también del periodismo para siempre. No obstante, al poco tiempo Palma recibirá la visita de Andrés Avelino Aramburú Salinas, propietario y ex-director de la revista Mundial, otra de las publicaciones que durante el oncenio prestaron su respaldo incondicional a Leguía ${ }^{60}$, quien le propone fundar mancomunadamente una hoja partidaria de apoyo a Arturo Osores, con el claro fin de disminuir las posibilidades de Sánchez Cerro de instalarse definitivamente en el poder. Palma acepta la propuesta de Aramburú y es así como nace el diario El Espectador.

58 Ibíd., cap. III, p.19.

59 PALMA, Clemente. Había una vez un hombre... Lima, C.I.P. Enrique Bustamante y Balliván, 1935, pp. 43-45.

60 SORIANO, Ana Luisa, y SICHES, Elizabeth. Catálogo de la literatura peruana publicada en la revista Mundial. Lima, Imp. P.L. Villanueva, S.A., 1987, pp.54-46 
Los comicios se llevan finalmente a cabo. Al efectuarse el cómputo de las elecciones, el Jurado Nacional de Elecciones proclama Presidente de la República a Sánchez Cerro con 152,062 votos. A Haya de la Torre se le reconoce 106,007, a la Jara 21,921, y a Osores 19,653. En todo el país los partidarios del aprismo protestan violentamente, porque afirman ser ellos los verdaderos ganadores de los comicios $^{61}$.

Pese al escándalo del fraude electoral, Sánchez Cerro juró el cargo de Presidente Constitucional el 8 de diciembre de 1931. Desde entonces la pugna entre el gobierno y la oposición fue grande, intensificándose cada vez más, dando lugar a que el régimen llamado de los "dieciséis meses", fuera pleno de incidencias políticas que hicieron vivir al país momentos de profunda intranquilidad.

Para reprimir a la oposición, el Congreso aprobó leyes muy severas que fueron enviadas por el Ejecutivo, entre ellas una llamada Ley de Emergencia (9-I-1932) que otorgó al gobierno poderes especiales, lo que le facultó apresar y deportar a 23 representantes de la minoría. Se clausuró la Universidad de San Marcos y las persecuciones, encarcelamientos y destierros fueron asunto de todos los días.

En su artículo $1^{\circ}$, la Ley de Emergencia proscribía de modo general los actos contrarios a las instituciones públicas y al bienestar social. En su artículo $2^{\circ}$ normaba las sanciones que debían aplicarse a los trasgresores del artículo $1^{\circ}$. La sanción más importante fue quizá la obligación que tenían los condenados por esos delitos al pago de una cierta cantidad de dinero, y si estos no podían abonar la suma asignada, sufrirían un día de prisión en el Panóptico por cada diez soles de oro de multa.

61 CHIRINOS SOTO, Enrique. Historia de la República (1821-1982), 2da. ed., Lima, Minerva, 1982, cap. XI, p.478. 
Al entrar en vigor la Ley de Emergencia un sinnúmero de publicaciones fueron multadas a partir del 15 de enero; entre las más importantes destacan los diarios La Noche, Buen Humor, Apra y La Revista Semanal. Luego, casi al mes, la razzia sanchecerrista sancionaría también a La Tribuna, La Crónica, El Hombre de la Calle, El Espectador y otras más ${ }^{62}$.

Conocida la sanción oficial Clemente Palma se negó rotundamente a pagar los 3,000 soles de multa que le impuso el Ejecutivo, por "ofender la respetabilidad de las instituciones del Estado" y "perturbar la paz y el orden público", y, por el contrario, siguió editando clandestinamente El Espectador que estaba bajo su dirección. Ante este desacato a la autoridad, el Ministro de Gobierno y Policía ordenó su arresto para ser llevado a la Isla San Lorenzo, luego se le trasladó al Panóptico, cárcel esta última desde donde partió deportado a Chile, país al que llegó junto con Federico More Barrionuevo, Ezequiel Balarezo Pinillos y otros colegas periodistas a finales de febrero de 1932.

Es curioso anotar que Chile era para Clemente Palma un lugar especial, por los recuerdos que su padre le había contado de sus dos años de residencia en tierras del Mapocho. Pero, por otra parte, no comulgaba mucho con el espíritu belicoso y la doblez que los chilenos nos habían mostrado durante largos años, debido al conflicto de Tacna y Arica ${ }^{63}$, resuelto con el Acuerdo de Lima de 1929. Mucho había escrito contra ese espíritu y sus autoridades políticas durante los casi 21 años que trató ese asunto internacional en sus conocidas crónicas tituladas "De Jueves a Jueves" de la revista Variedades ${ }^{64}$.

62 NORABUENA, Teodorico. La libertad de prensa en el Perú. Lima, ed. particular, 1982, parte II, cap. IX, p.13I.

63 Véase PALMA, Clemente. La cuestión de Tacna y Arica y la conferencia de Washington. Lima, Casa Editora Manuel Moral, 1922.

64 Véase ADRIAZOLA SILVA, Juan Carlos. La Revista Variedades y las crónicas De 
El clima social y político que se vivía en Chile al llegar Clemente, no era mejor que el del Perú. Varios gobiernos de transición se sucedían uno tras otro, como fiel reflejo de la inestabilidad que reinaba en el país: Juan Esteban Montero Rodríguez (4/12/3116/6/1932), Carlos Dávila Espinoza (16/6/1932- 13/9/1932), general Bartolomé Blanche Espejo (13/9/1932 - 2/10/1932)), Abraham Oyanedel Urrutia (2/10/1932 - 4/12/1932), Arturo Alessandri Palma ( $2^{\circ}$ gobierno) (24/12/1932 - 24/12/1938).

Después de arribar al puerto de Valparaíso, Clemente Palma se dirigió casi de inmediato a Santiago de Chile, donde debió buscar un lugar donde vivir y trabajar. No quiso quedarse en la ciudad-puerto de Valparaíso como fue el caso de su padre setenta y dos años atrás. No gustaba mucho del paisaje soleado y alegre que le ofrecía el mar y su gente; prefirió, por el contrario, el ambiente citadino y frío de la gran urbe andina, pues iba más acorde con su personalidad ${ }^{65}$. Además, creyó tomar una buena decisión, ya que los principales círculos culturales y sociales se hallaban entonces focalizados en la capital del Mapocho ${ }^{66}$.

Jueves a Jueves de Clemente Palma sobre el conflicto peruano chileno de Tacna y Arica (1908-1929) (Tesis inédita de periodismo), Piura, Universidad de Piura, 1991.

65 El carácter y otros rasgos de la psicología de Clemente Palma fueron siempre especiales. Era, además, un hombre que gustaba transmitir una imagen de persona misteriosa, lacónica, huraña al trato social. Véase ADRIAZOLA SILVA, Juan Carlos. "Clemente, el primogénito de don Ricardo Palma”. En Aula Palma, $\mathrm{n}^{\circ}$ VIII, Lima, Instituto Ricardo Palma, Universidad Ricardo Palma, 2009, pp.213-234.

66 Santiago de Chile o simplemente conocido como Santiago, era la capital de la República y de la provincia y departamento del mismo nombre, además de ser la sede arzobispal más importante del país. La historia de Santiago de Chile se remontaba a los primeros habitantes de la cuenca del río Maipo, aproximadamente en el X milenio a. C. Sin embargo, recién en el siglo XV con la conquista de la región por el Imperio inca existirían las primeras comunidades en la zona. La ciudad española fue fundada con el nombre de Santiago de la Nueva Extremadura (Santiago del Nuevo Extremo), por el conquistador Pedro de Valdivia, el 12 de febrero de 1541. De tal modo, que gente de raigambre y solar daban timbre a la ciudad. Geográficamente, la ciudad estaba ubicada a 520 m.s.n.m., en el gran valle intermedio chileno, sobre terreno llano un 
En carta fechada el 20 de febrero de 1932, dirigida a su esposa María Manuela Schmaltz le dice:

"He podido conseguir pronto y con una buena renta un pequeño piso alto en la calle de Teatinos, en donde, cada mañana, al abrir las ventanas, observó a lo lejos la imponente Cordillera de los Andes y sus gélidos picachos. Ayer pude salir a ver el Mapocho, y cruzar su antiquísimo puente de cal y canto, que aún conserva la gracia que debió tener antaño (..." ${ }^{\prime 67}$.

Como capital de la República de Chile, Santiago era residencia de los altos poderes del Estado y sede de los cuerpos diplomático y consular acreditado ante el gobierno, y como ciudad opulenta poseía cuantas comodidades y adelantos ostentaban las grandes urbes latinoamericanas en la primera mitad del siglo XX (bellos edificios públicos, teatros, cafés, museos, cines, tiendas, clubs, bibliotecas, hospitales, etc.). Contaba entonces la ciudad con numerosas estaciones de ferrocarril para el tráfico de pasajeros, las más importantes eran: "Alameda", de donde partían y adonde llegaban los trenes que unían a la capital con las provincias del Sur de Chile; "Mapocho”, que servía al ferrocarril transandino que comunicaba con la República Argentina, al tren electrificado que unía a la ciudad con Valparaíso, y al tren que viajaba a la provincias del Norte del país. La ciudad de Santiago, por su parte, estaba conectada internamente por una

poco inclinado hacia el Oeste y el Sur, distante 2 horas y media del Océano Pacífico y a 15 o $16 \mathrm{~km}$. de la base de los Andes, que se levanta a su vista por el Este en toda su grandiosidad y por el centro atraviesa la ciudad el río Mapocho de donde nace el adjetivo y gentilicio de "mapuche", "mapochino" o "mapochina", dado en honor de los antiguos habitantes amerindios del centro y centro sur de Chile.

67 A finales de la década de los 80 del siglo XX, cuando preparábamos nuestra tesis universitaria, tuvimos acceso al archivo y biblioteca personal de Clemente Palma que aún conservaba su descendiente Sr. Alejandro Palma Garland, en la casa donde vivió hasta sus últimos años nuestro personaje, calle Manco Cápac N³47, Miraflores, Lima. 
eficiente red de tranvías que cubría tanto su parte llana como los cerros quela rodeaban. La población santiaguina en 1932 ascendía, según prospección del censo de $1920^{68}$, a unos 750 mil habitantes.

Clemente, gracias a algunas amistades prominentes, pronto pudo hallar un puesto de crítico literario en El Mercurio, el más grande y más influyente diario de la capital chilena. En este periódico llegó a publicar asimismo varios de los cuentos que integraban las ediciones de Cuentos Malévolos o Historietas Malignas. Aunque también dio a la luz nuevos relatos que no estaban comprendidos en sus libros anteriores, tales como: "El hombre del cigarrillo" (edición del 4/9/1932, sección primera, p.l) "La aventura del hombre que no nació" (edición 4/1/1933, sección primera, p.1), etc.

A las pocas semanas de haber llegado a Chile, Palma recibió del doctor Jorge Adolfo Mitre, director del diario La Nación de Buenos Aires una invitación para trasladarse inmediatamente a la Argentina donde le prometían un trabajo de nivel y bien remunerado, pero Clemente se excusa de aceptar el ofrecimiento por razones sentimentales: en el Perú había quedado su esposa María Manuela y sus cuatro hijos; Edith, Clemencia, Clemente y Ricardo, y pensada que permaneciendo en Chile estaría más cerca de los suyos. Comprendiendo las razones expuestas por Palma, los directores de La Nación no insistieron más en su propósito, sin embargo, se permitieron contratarlo como colaborador extranjero ${ }^{69}$.

68 El censo de 1920 registraba 507,313 habitantes. Cfr. Enciclopedia Universal Ilustrada Europea Americana Espasa-Calpe, ed. 1927, Madrid, t.54.

69 Cfr. PALMA, Clemente. XYZ/Novela grotesca. Lima Imp. Perú Actual, 1935, p.7 


\section{Lo mejor de la prosa en el destierro: $X Y Z$, Novela grotesca}

Si bien para Clemente Palma el destierro fue difícil y penoso de sobrellevar por hallarse lejos de su familia y por la posición económica venida a menos, también es verdad que con el exilio vino algunas satisfacciones interiores, ya que pudo hacer una intensa vida cultural en la capital del Mapocho; y, sobre todo, se dio tiempo para revisar una serie de papeles y esbozos literarios que había llevado como parte de su modesto equipaje. Estos proyectos inconclusos son los que darán al escritor peruano el solaz y el ánimo necesario para soportar las contrariedades que tiene que afrontar ese tiempo extrañado de su patria. En el prólogo de su obra Palma expresa:

Deportado a Santiago de Chile por el más deplorable gobernante que ha sufrido mi patria (...), pasé año y medio en la culta capital chilena, lejos de los míos y procurando ganarme la vida modestamente como Dios me diera a entender.

En los ratos de ocio y de soledad, que han sido bastantes, he distraído mis nostalgias recordando que otrora, cuando el periodismo no me había cogido aún entre sus garras, había sido, por vocación hereditaria sin duda, algo literato (...).

Ha sido necesario que el destierro con que se quiso eliminarme o castigar virtudes o pecados de periodista y de político, me hiciera hurgar el cofre de los recuerdos, encontrando en un rincón de mi espíritu el olvidado y proyectado deseo de escribir una novela sobre el cine ${ }^{70}$.

De esta experiencia santiaguina, nacerá la obra que Palma titulará dos años después $X Y Z$, la cual, a renglón seguido lleva como subtítulo el de: Novela grotesca, pues su autor consideraba que este relato

70 Loc. cit., pp.7-8. 
"extravagante" e "irregular" era fruto de la aventura, la osadía y la falta de técnica literaria; pero que, para él, había sido imprescindible volcar en letras de molde, pues constituyó para su imaginación e inteligencia todo un reto en un contexto de proscripción.

Dentro del género novelístico, $X Y Z$ es la obra literaria más importante de Clemente Palma. Esta tiene como antecedente la novela L'Évefuture del conde Auguste Philippe Villiers de L' Isle-Adam, publicada en París en 1886. El relato del escritor francés traza una de las novelas proféticas de la civilización mecanicista, en la que la humanidad entera quedará avasallada por los logros y el prestigio que alcancen los descubrimientos técnicos y científicos. En $X Y Z$ Palma desarrollará a lo largo de sus páginas un atrevido juego fantástico: la historia de un hombre de ciencia norteamericano que, mediante la prodigiosa invención del cinematógrafo y ciertas experiencias biológicas, intenta recrear la vida humana, pero no cualquier vida sino la de las reinas de la nueva mitología cientifista del cine.

¿Cómo nace en Palma la idea de crear esta obra literaria? Él mismo nos lo cuenta:

En las noches, estimulado por mi antigua afición a los esparcimientos que la ciencia metida a artista ha inventado -el Cine y la Radioconcurría en veces a los teatros para entretenerme un rato con los pastiches dramáticos, aventureros o cómicos que se desenvuelven en la pantalla, y que antes tenían para mí el prestigio de subsistir con meras leyendas sintéticas lo que generalmente había de más malo en las obras teatrales: la letra. Pero el cine sonoro nos ha traído -cierto que hasta ahora en alguna discreción- la inclusión de la palabra humana. Menos mal que también nos obsequia con la voz de la naturaleza y de la vida de las $\operatorname{cosas}^{71}$

71 Ibíd. p. 123 
No olvidemos que desde finales de la década de 1920 los actores y actrices hollywoodenses, gracias a la distribución internacional que se hacía de las películas sonoras, extendieron su fama por todo el mundo occidental, y una fiebre de "fans" comenzó a surgir por doquier, ya sea porque veían en esos artistas plasmados sus ideales de belleza y éxito, ya sea porque los tomaban como modelo de personalidad o estilo de vida. Esta es la época en que Riccioto Canudo empieza a hablar del cine como "séptimo arte" y los actores, merced a la publicidad de sus productoras y a la prensa de espectáculos, son elevados a la categoría de "estrellas cinematográficas". Fue así como se iniciaron los mitos de Max Linder, Sarah Bernhardt, Chaplin, Mary Pickford, Rodolfo Valentino, Gloria Swanson, Víctor Seaströn, Greta Garbo, Edward Robinson, Marlene Dietrich y, muchas estrellas más que conformaban verdaderas constelaciones $\operatorname{artísticas~}^{72}$.

El éxito que rápidamente obtiene el cine sonoro da pie a Palma para experimentar con audacia imaginativa un tema novelístico nunca antes tratado en el Perú o en el contexto hispanoamericano. Al mismo tiempo que audacia imaginativa, $X Y Z$ revela el trato sistemático que su autor hace de los descubrimientos científicos de su época (por ejemplo, el del Radio hecho por los esposos Curie), y trasluce en ella su propósito de satirizar a los hombres de ciencia ensoberbecidos por su aparente dominio de la materia, y que en el intento de penetrar en los incógnitos dominios del espíritu humano, fracasan trágicamente ${ }^{73}$.

72 Cfr. MENDEZ-LEITE, Fernando. El cine norteamericano / Historial y trayectoria. Madrid, Gráficas Sánchez, 1942, pp.41-163.

73 Cfr. CASTRO ARENAS, Mario. La novela peruana y la evolución social. Lima, José Godard Editor, 1970, p.130. 


\section{Homenajes chilenos por el primer centenario del nacimiento de Ricardo Palma}

Tan pronto como Clemente Palma llegó a la capital del Mapocho, visitó varias instituciones representativas de inteligencia chilena. En ese periplo, que inició en las primeras semanas de febrero de 1932, se dio tiempo para conocer de modo particular la Biblioteca Nacional de Chile, dirigida entonces por Tomás Thayer Ojeda (período 1931-32), quien tuvo la cortesía de recorrer con el hijo del tradicionista las salas del principal centro bibliográfico de ese país. En dicha visita, Palma pudo, por primera vez, conocer en persona y estrechar la mano de don Guillermo Feliú Cruz ${ }^{74}$, a la sazón Conservador de las Bibliotecas legadas por Diego Barros Arana (en 1920) y José Toribio Medina (en 1925). En el primer recinto bibliotecario de Chile, Feliú Cruz mostró de forma entusiasta a Clemente Palma los manuscritos que preparaba para su proyectado libro: En torno de Ricardo Palma. El propio Feliú cuenta acerca de este encuentro a don José de la Riva Agüero, en carta fechada en Santiago de Chile, el 14 de febrero de 1933:

Queriendo darle una gran sorpresa para su amor filial, le hable de mi libro y luego le franqueé los manuscritos. Su juicio sobre mi libro me llenó de satisfacción. Conocedor como usted de la obra de don Ricardo, concluyó expresándome que lo consideraba definitivo y completo desde el punto de vista abordado por mí: el bibliográfico-crítico ${ }^{75}$.

74 Cfr. Carta de Guillermo Feliú Cruz a José de la Riva Agüero, fechada en Santiago de Chile, el 14 de febrero de 1933. En RIVA AGÜERO, José de la. Epistolario Fabián-Guzmán (Obras Completas XVI), vol. I, Lima, Publicaciones del Instituto Riva Agüero n²60, Pontificia Universidad Católica del Perú, 1999, p. 57.

75 Loc. cit. 
Por otra parte, Clemente recordó en esa visita a la Biblioteca Nacional de Chile, que el 7 de febrero del año siguiente se conmemoraría el primer centenario del nacimiento de su padre, lo que sus interlocutores tomaron con gran ánimo y, desde ya, se habló de una posible celebración institucional. Feliú insistió que una forma práctica de patentizar esa celebración sería la publicación de sus manuscritos. Clemente asintió en la propuesta, y ofreció escribir a su hermana Angélica que se hallaba en Lima para lograr, por intersección del flamante embajador del Perú en Chile don Pedro Irigoyen, que la Universidad de San Marcos pudiera pagar la edición de ese importante aporte a los estudios de la vida y obra del Padre de las Tradiciones. En efecto, Angélica tocó las puertas de la Decana de América, pero dada la coyuntura política, el gobierno sanchecerrista no vio con buenos ojos que alguien vinculado directamente a un deportado político -Clemente Palma- recibiera ese tipo de ayuda, y no le importó -mezquinamente, por cierto- si ese personaje a homenajear era don Ricardo Palma, quien tanto había hecho en su vida por poner en alto el nombre del Perú. Sobre el particular, Feliú apenado, inquiere:

Las gestiones [de Angélica] parecieron alcanzar un éxito halagador; mas, parece que las cuestiones políticas han impedido que ellas tuviesen un resultado positivo, por tratarse de Palma, cuyo hijo esta deportado en esta. [Este es] un libro que interesa al Perú, que está hecho con todo amor y cariño y que es la manifestación de un chileno a una de las glorias más puras y altas de ustedes. ¿Cómo es posible que el gobierno y la Universidad, por muy fuertes que sean las asperezas políticas, no puedan comprender el sentido de cultura, de honor, de gloria, que entraña para el Perú el reconocimiento de un extranjero? ${ }^{76}$.

76 Loc. cit., p. 57-58. 
El embajador Irigoyen como una forma de ayudar a don Guillermo Feliú Cruz, tan pronto como arribó a Santiago de Chile, le hizo entrega de \$3,153 pesos, con el propósito de que empiece la impresión del libro, y la esperanza de que haría lo posible para obtener de la Universidad el dinero faltante y así completar el pago total de la edición. Lamentablemente, la Universidad fue clausurada por la crisis política y el gobierno sanchecerrista se desentendió del asunto del centenario palmista por completo, ya que por esos días le preocupaban más los asuntos de orden internacional. Es entonces que Angélica Palma le pide a Guillermo Feliú escriba a su amigo el doctor José de la Riva Agüero y Osma, quien tenía ya conocimiento de la situación, y era la última esperanza que les quedaba para que el libro no naufragara. En ese contexto, Feliú expresa a Riva Agüero estas sinceras y humildes palabras:

Debo hablarle con entera franqueza. Si yo hubiese previsto el género de dificultades que se han presentado, por nada habría hecho imprimir el libro. Pero con la ayuda del señor Irigoyen y en la convicción absoluta del apoyo del Gobierno o de la Universidad, cometí el error de avanzar la obra. Soy reo de precipitación. Tampoco he solicitado para mí ninguna clase de honorario y estoy dispuesto a entregar los 500 ejemplares que se han tirado en la siguiente forma: 250 para usted y 250 para el señor Irigoyen. Creo que tanto usted, como el señor Embajador, a título de autor y de padre de este desdichado libro podrán concederme, cada uno 50 ejemplares. Por lo demás, el libro les será dedicado.

Lo que resta para cubrir totalmente la edición son ocho mil pesos chilenos que, reducidos a moneda peruana o dollares, significa una suma muchísimo menor que la que representa en la nuestra. Para mí, escritor, profesor y servidor público y caballero ante todo, me es doloroso tener que suplicar una ayuda que muy bien comprendo en el alto significado de usted como hombre culto y que sabe el 
valor de estas cosas, pero que me es profundamente dolorosa. Sin embargo, el ofrecimiento de usted compromete mi gratitud de tal manera que usted nunca llegará a comprenderlo y me habla muy alto del patriota y del escritor que, con su nombre y su obra, honra a su patria ${ }^{77}$.

Finalmente, el libro En torno de Ricardo Palma, impreso en las Prensas de la Universidad de Chile, vio la luz a mediados del año 1933. Y como lo prometió anticipadamente su autor, fue dedicado a las tres personas capitales que coadyuvaron a su alumbramiento:

Inscribo aquí tres nombres peruanos ilustres en el recuerdo de la amistad literaria: el de don José de la Riva Agüero y Osma, Presidente de la "Sociedad Amigos de Ricardo Palma" y el de don Pedro Irigoyen, Embajador del Perú en Chile, a cuyos esfuerzos generosos y desinteresados, débese la publicación de esta obra. Y también el de don Clemente Palma, virtuoso exiliado de su patria entre nosotros, hijo del tradicionista, que alentara al autor a dar forma de libro a un manuscrito que parecía condenado al olvido.

En torno de Ricardo Palma es una obra dividida en dos volúmenes, el primero de ellos, "Estancia en Chile" (255 pp.) recoge una extensa biografía del tradicionista, en donde se explica las razones menudas de su deportación y las principales actividades en las que participó durante su permanencia en la tierra del Mapocho (1860-1862). El segundo volumen, está dedicado a un "Ensayo critico-bibliográfico" (399 pp.) que recoge de forma cronológica y descriptiva todo lo publicado en vida por el tradicionista. Es realmente una investigación valiosísima, que vino a enriquecer de forma notable la bibliografía palmista en la primera mitad del siglo XX.

77 Loc. cit., pp.58-59. 
Aparte del libro arriba señalado, la ceremonia pública más importante que se realizó en las tierras del Mapocho para rendir tributo a don Ricardo Palma por el primer centenario de su nacimiento, y en la que participó directamente su hijo Clemente, se realizó en la Biblioteca Nacional de Chile, el 7 de febrero de 1933. Para entonces, el nuevo director de la Biblioteca el presbítero Alejandro Vicuña Pérez (período 193235), se esmeró en preparar un nutrido programa de actividades que contó con la asistencia de diversas personalidades locales y extranjeras que se sumaron al homenaje de quien era considerado no solo en Chile sino en toda Hispanoamérica como el "Padre de las Tradiciones".

El acto de confraternidad americana, que resultó imponente, se vio prestigiado con la presencia de miembros del cuerpo diplomático, entre los cuales estaban los señores: William S. Culbertson, Embajador de Estados Unidos; Marcial Martínez de Ferrari, Embajador de Chile en Brasil; Isidro Ramírez, Ministro del Paraguay; Ricardo Sánchez Ramírez, Ministro de Colombia; Tulio Cesteros, Ministro de la República Dominicana; N. Norweb, Secretario de la Embajada de Estados Unidos; y Javier Delgado Irigoyen, Secretario de la Embajada del Perú. También se advertía en la espaciosa sala la presencia de don Elías Errázuriz; de los distinguidos miembros de la colonia peruana residente tanto en Santiago como en Valparaíso; de los altos funcionarios de la Biblioteca Nacional y de la Biblioteca del Congreso, y, finalmente, de numerosos profesores, estudiantes, escritores y púbico selecto. Presidieron el acto, en los sillones de honor, Ricardo Boza Aizcorbe, Encargado de Negocios del Perú, el presbítero Alejandro Vicuña Pérez, Director de la Biblioteca Nacional, y Clemente Palma, en representación de la familia del homenajeado ${ }^{78}$.

78 Cfr. SOCIEDAD AMIGOS DE PALMA. Ricardo Palma 1833-1933. Lima, Compañía de Impresiones y Publicidad, 1934, pp.182-183. 


\begin{abstract}
Al hacer uso de la palabra en la ceremonia de los homenajes chilenos, el primogénito de don Ricardo Palma, notoriamente emocionado, dijo a las autoridades y a los asistentes:
\end{abstract}

Señor Director de la Biblioteca Nacional de Santiago: Mi padre fue el restaurador de la Biblioteca Nacional de Lima, y como usted, amó los libros; fue apreciador entusiasta de la bibliografía chilena, y tuvo singular empeño en enriquecer esta sección del establecimiento de su cargo, poniendo a contribución amistosa a los hombres de letras de Chile y a los institutos culturales. Huésped de este país, por azares de la política peruana, como lo soy yo, setenta años después, le sirvieron las relaciones afectuosas y de camaradería literaria que conservó con los más eminentes intelectuales de Chile, al margen del distanciamiento en que vivieron desgraciadamente nuestros países[durante y después de la Guerra del Pacífico]. Al honrar usted en esta actuación al viejo bibliotecario peruano desaparecido de la vida hace trece años, ha respondido usted a la nobleza justiciera y a la hombría de bien, que es la más bella característica de los hombres de Chile. Acepte usted, señor, el homenaje de mi gratitud, mucho más profunda de lo que puede percibirse en estas pálidas frases. (...)

Señor Boza, Encargado de la Embajada del Perú: particularmente grato ha sido para mí escuchar las palabras de contribución de usted, en representación del actual gobierno del país, del que soy franco adversario, en este significativo homenaje de la más alta institución cultural de Chile a mi padre. Las hondas preocupaciones de orden internacional que distraen la atención del gobierno peruano, no le han permitido sin duda tributar a la memoria centenaria de uno de los más representativos valores literarios, los honores que en Lima merecía el tradicionista de su ciudad natal ${ }^{79}$. Algún día

79 No es tan cierto lo que afirma Clemente Palma de que en Lima se pasó inadvertido el centenario de su padre, pues sí existió una Comisión ProCentenario que la encabezó el Concejo Provincial de Lima e integró la Biblioteca Nacional, la Sociedad Geográfica, el Consejo Nacional de Mujeres 
será. Entretanto, para usted, mi personal, sincero y emocionado agradecimiento.

Señoras y señores: Vuestra presencia en esta generosa actuación, que es exponente de la cultura nacional y del afecto leal de estas dos naciones que juntas nacieron a la vida civilizada, y juntas desenvolvieron su vida colonial y republicana, compromete de forma inolvidable mis sentimientos, porque sois el alma simpática, la concreción y substancia de esta manifestación de respeto y admiración a la obra que realizó el ilustre escritor cuya memoria honráis. Al daros las gracias con toda mi alma hago votos porque la historia futura de nuestros pueblos, hermanos en la historia pasada, robustezca sin interrupciones y afirme inquebrantablemente una tradición fecunda en bienestar y fuerza para el porvenir, la tradición de la fraternidad peruano-chilena ${ }^{80}$.

\section{El regreso al Perú}

Muerto Sánchez Cerro a manos de un victimario, el 30 de abril de 1933, la dictadura por él instaurada se vino pronto a tierra. Los deportados políticos, sin embargo, no pudieron regresar de inmediato al país. El Congreso, para completar el período de Sánchez Cerro (1931 - 36), designó al general Oscar R. Benavides como Presidente Provisorio.

del Perú, la Sociedad de Bellas Artes, la Asamblea de las Sociedades Unidas, entre otras más. Asimismo, La "Sociedad Amigos de Palma", aparte de un nutrido Programa de festejos, editó un libro conmemorativo el 7 de febrero de 1934, gracias siempre al apoyo económico de Riva Agüero, con el título de Ricardo Palma 1833-1933. En este libro de homenaje de 342 pp., aparecerán dos trabajos importantes de Clemente Palma: "En torno al centenario de Ricardo Palma" (pp.207-215) y "La tradición, los tradicionistas y las cosas de Ricardo Palma” (pp. 217-231).

80 SOCIEDAD AMIGOS DE PALMA. Ricardo Palma 1833-1933. Lima, Compañía de Impresiones y Publicidad, 1934, pp.201-202. 
El 26 de junio de 1933 Benavides encomienda la presidencia del Consejo de Ministros a Jorge Prado y Ugarteche, quien da a conocer ante la Asamblea Constituyente un programa llamado de "apaciguamiento y concordia", y obtiene el voto de confianza esperado. No obstante, la Ley de Amnistía para los deportados políticos recién será expedida el 9 de agosto.

Al retornar a Lima, Clemente Palma encuentra que muchas cosas que había dejado antes de su partida habían cambiado o desaparecido, entre estas últimas, el cierre definitivo de la revista Variedades fue lo que más desazón causó a su espíritu. Sin embargo, había que seguir adelante y recuperar pronto el tiempo perdido. Chile fue para el primogénito de don Ricardo Palma una experiencia excepcional que le permitió comparar la vida desde otros ángulos distintos a los acostumbrados; pero sobre todo tuvo el honor y la grande alegría de ser testigo de excepción de los homenajes que tributaron a su padre los hijos más connotados de las tierras del Mapocho.

\section{A modo de conclusión}

La vida de don Ricardo Palma y su hijo Clemente tienen en común el destierro político en Chile. No lo vivieron al mismo tiempo, pues entre uno y otro suceso hay una distancia de 72 años. El primero por haber participado en una aventura política contra el general Ramón Castilla, el segundo por su consecuencia y lealtad al presidente Augusto Leguía a quien estaba agradecido y estimaba verdaderamente, incluso después de muerto. Para ambos -padre e hijo- fueron experiencias que los marcaron mucho. Más quizá a Ricardo, quien a sus 27 años de edad enfrentó los sinsabores de la soledad y la carencia del afecto familiar (que únicamente le prodigaba en Lima don Pedro, su padre), además de la pobreza que le asechaba 
constantemente. Era, además, un hombre en formación con ganas de seguir aprendiendo y hacer obra grande. Clemente, en cambio, era ya un hombre cuajado de 60 años, escritor y periodista con prestigio continental, el cual vivió con mucho estoicismo la lejanía de su patria, aunque no por ello desamorado u olvidando a su mujer y a sus cuatro hijos que habían quedado en Lima, solo a merced de los giros de dinero que solía enviarles desde Santiago.

Tanto en el caso de Ricardo como el de Clemente, el destierro chileno les dio la oportunidad de producir intelectualmente lo que mejor sabía hacer cada uno. El primero, aportó a su corpus literario dos obras señeras: en poesía, Armonías. Libro de un desterrado. Y en prosa, Anales de la inquisición de Lima. Esta última, sobre todo, anclada en el pasado, tiempo que le era muy caro al tradicionista. Clemente, por su parte, pudo crear su XYZ. Novela grotesca. Un relato suscitado a raíz de la expansión de la cinematografía, adelanto audiovisual que por esos días comenzaba a causar furor en el mundo occidental.

Chile -su tierra y su gente- fue tanto para don Ricardo como para Clemente el espacio que los cobijó en una etapa difícil de sus vidas. Además, les dio la oportunidad de continuar perfeccionándose. Porque el hombre no es un ser perfecto sino perfectible a lo largo del tiempo. Cualquiera sean los años que tenga, el hombre necesita de las personas, las cosas y los lugares para seguir en su proceso natural de perfeccionamiento, a fin de ser más humano, más tolerante, más comprensivo. Justamente para que nada de lo humano le sea extraño. 


\section{Bibliografía}

ADRIAZOLA SILVA, Juan Carlos. "Clemente, el primogénito de don Ricardo Palma”. En Aula Palma, n VIII, Lima, Instituto Ricardo Palma, Universidad Ricardo Palma, 2009, pp.213-234. paterno-filiales". En Aula Palma, n X, Lima, Instituto Ricardo Palma, Universidad Ricardo Palma, 2011, pp. 239-271.

La Revista Variedades y las crónicas De Jueves a Jueves de Clemente Palma sobre el conflicto peruano chileno de Tacna y Arica (1908-1929) (Tesis inédita de periodismo), Piura, Universidad de Piura, 1991.

ÁlVAREZ CALDERÓN, María Delfina. El saqueo olvidado a la casa de Augusto B. Leguía: 1930. Lima, Titanium Editores, 2013.

BASADRE, Jorge. Historia de la República del Perú 1822-1933. Lima, Editorial Universitaria, S.A., 1970. Tomos del I al XVII.

CASTRO ARENAS, Mario. La novela peruana y la evolución social. Lima, José Godard Editor, 1970.

CHIRINOS SOTO, Enrique. Historia de la República (I8211982), 2da. ed., Lima, Editorial Minerva, 1982.

ENCICLOPEDIA UNIVERSAL ILUSTRADA EUROPEA AMERICANA ESPASA-CALPE, ed. 1927, Madrid, t.54.

FUENTES, Manuel-Atanasio. Guía del viajero en Lima. Lima, Librería Central, 1860. [Edición Facsimilar] (+La Ciudad de los Reyes, estudio preliminar de César Coloma Porcari) Lima, Instituto Latinoamericano de Cultura y desarrollo, 1998. 
FELIÚ CRUZ, Guillermo. En torno de Ricardo Palma. Santiago de Chile, Prensas de la Universidad de Chile, t. I y t. II, 1933.

HAMPE, Teodoro. "Ricardo Palma cronista de la Inquisición". En Aula Palma, $\mathrm{n}^{\circ}$ IV, Lima, Instituto Ricardo Palma, Universidad Ricardo Palma, 2003-2004, pp.145-164.

HOLGuín CALlO, Oswaldo. Tiempos de infancia y bohemia Ricardo Palma (1833-1860). Lima, Fondo Editorial Pontificia Universidad Católica del Perú, 1994.

Páginas sobre Ricardo Palma. Lima, Editorial Universitaria, Universidad Ricardo Palma, 2001.

LEGUÍA, Augusto B. Yo tirano, yo ladrón (Memorias del Presidente Leguía). Lima, Editorial “Ahora” S.A., 1934 (?).

MENDEZ-LEITE, Fernando. El cine norteamericano / Historial y trayectoria. Madrid, Gráficas Sánchez, 1942.

MINISTERIODERELACIONES EXTERIORES [de Colombia]. Informe al Congreso de 1931. Bogotá, Imp. Nacional, 1931.

NORABUENA, Teodorico. La libertad de prensa en el Perú. Lima, ed. particular, 1982.

OVIEDO, José Miguel. Genio y figura de Ricardo Palma. Buenos Aires, Editorial Universitaria de Buenos Aires, 1965.

PALMA, Ricardo. Tradiciones peruanas completas.- Edición y prólogo de Edith Palma (nieta del autor) Madrid, Aguilar, 1957. 
Epistolario general 1846-1891. T. I (Edición, prólogo, notas e índices de Miguel Ángel Rodríguez Rea). Lima, Editorial Universitaria, Universidad Ricardo Palma, 2005.

Anales de la Inquisición de Lima (Edición Facsimilar en base a la 3ra. ed. de Madrid de 1897). Lima, Ediciones del Congreso de la República del Perú, 1997.

Obra poética de Ricardo Palma (compilada por Merlin Compton). Lima, Biblioteca Nacional del Perú, 2000.

PALMA, Angélica. Ricardo Palma. [Edición del centenario del Tradicionista (7 de febrero de 1993) con numerosas ilustraciones documentales] Buenos Aires, Ediciones Argentinas "Cóndor", 1933.

PALMA, Clemente. Había una vez un hombre... Lima, C.I.P. Enrique Bustamante y Balliván, 1935.

XYZ /Novela grotesca. Lima, Ediciones Perú Actual, 1935.

La cuestión de Tacna y Arica y la conferencia de Washington. Lima, Casa Editora Manuel Moral, 1922.

Narrativa Completa. (Edición, prólogo y cronología de Ricardo Sumalavia). Lima, Ediciones del Rectorado, Departamento de Humanidades, Pontificia Universidad Católica del Perú, 2006. Tomos I y II.

RIVA AGÜERO, José de la... "D. Ricardo Palma”. En Mercurio Peruano. Lima, enero 1919, Año II, vol. IV, n¹9. 
Epistolario Fabián-Guzmán (Obras Completas XVI), vol. I, Lima, Publicaciones del Instituto Riva Agüero n ${ }^{\circ} 260$, Pontificia Universidad Católica del Perú, 1999, pp.56-59.

SOCIEDAD AMIGOS DE PALMA. Ricardo Palma 1833-1933. Lima, Compañía de Impresiones y Publicidad, 1934.

SORIANO, Ana Luisa, y SICHES, Elizabeth. Catálogo de la literatura peruana publicada en la revista Mundial. Lima, Imp. P.L. Villanueva, S.A., 1987.

VEGAS GARCÍA, Ricardo. Las presidentas del Perú. Lima, Fondo Editorial de la Biblioteca Nacional del Perú, 2002.

VILLALBA, Jorge. Manuela Sáenz /Epistolario. Quito, Ediciones del Banco Central del Ecuador, 1986.

VILLIERS DE LISLE-ADAM, Philippe Auguste. La Eva futura. (Traducción de Mauricio Bacarisse, Prólogo de Agustín Izquierdo). Madrid, El Club de Diógenes/Valdemar, 1998. 